\title{
THE RELATIONSHIP BETWEEN SOFT SKILLS TRAINING AND DEVELOPMENT, HUMAN RESOURCE OUTCOME AND FIRM PERFORMANCE
}

\author{
Bee-Lan Lok* \\ Universiti Tunku Abdul Rahman \\ Ming-Yu Cheng \\ Universiti Tunku Abdul Rahman \\ Chee-Keong Choong \\ Universiti Tunku Abdul Rahman
}

\begin{abstract}
The purpose of this paper is to investigate the impact of soft skills training and development on human resource outcome and firm performance. Data were collected from 199 manufacturers in Malaysia using questionnaire survey method and analysed using 'structural equation modelling' methodology. The results indicated that the relationship between soft skills training and development and firm performance is fully mediated by the human resource outcomes. This study highlights the indirect contribution of soft skills training and development on firm performance via its impacts on human resource outcome.
\end{abstract}

Keywords: Soft Skills, Training and Development, Human Resource Outcome, Firm Performance.

Received: 20 October 2019

Accepted: 30 December 2020

https://doi.org/10.33736/ijbs.3184.2021

\section{INTRODUCTION}

Malaysia's economic and social development for the past few decades has been impressive (Organisation for Economic Co-operation Development (OECD), 2016). Its remarkable growth trajectory and transformation was broadly fuelled by two sectors: (i) traditional sector, which includes oil and gas and tree crops (oil, palm rubber); and (ii) electrical and electronics (E\&E) sector. The recent World Bank report (2018) indicates that Malaysia has become the leading exporter of electrical appliances, electronic parts and components and natural gas. The manufacturing sector is the second key contributor and an impetus to the economy of Malaysia, contributing an average of $23.45 \%$ to the country's GDP for the past five decades and $12.33 \%$ of the total employment (Department of Statistics, Malaysia (DOSM), 2019; World Bank, 2020; Economic Planning Unit, 2020). From 2016 through 2019, the number of employees working in the manufacturing industry has increased by $12.17 \%$.

\footnotetext{
- Corresponding author: Faculty of Accountancy and Management, Universiti Tunku Abdul Rahman, Sungai Long Camus, Malaysia; Email: lokb12018@gmail.com
} 
Today, as the world ventures into the new millennium of the Fourth Industrial Revolution (4IR), where the 'real' and the 'virtual' worlds are seamlessly connected, it gives rise to what are known as cyber-physical production systems. This revolution brings a higher level of automation and interconnectivity in the manufacturing process and creates an enormous transformation in the approach to manufacturing. It is envisaged that employees' roles will change in terms of the work contents, processes and environment. The changes will result in less simple manual tasks available for semi-skilled workers. The traditional clear division of labour in manufacturing will change to a much more complex environment with new operational and organisational structures requiring more decision making, co-ordination, control and support services to co-ordinate between virtual and real machines and plants in production management systems. In line with the above changes, there will be a higher demand for employees with greater initiative and excellent communication skills to organise work that is more complex and involves a higher level of abstract thinking and problem-solving. According to the study conducted by the Economist Corporate Network (2016) on skills required by employers in Asia, 71.9\% of the CEOs who participated in the survey felt that soft skills are more important than hard skills for their business. Hard skills can be easily acquired while soft skills are much more difficult to build. The past studies had shown that there was a shortage of the soft skills demanded by employers. For instance, the study conducted by Aulbur, Arvind, and Rigghe (2016) of Federation of Indian Chambers of Commerce and Industry (FICCI) and Roland Berger (RB), shows that skills mismatch exists between the skill sets acquired by job applicants, and those expected by employers. This skills gap will widen in the 4IR era if no actions are taken. Similarly, past studies conducted on Malaysian graduates showed that soft skills shortages did exist in Malaysia (Ibrahim, Boehannoeddin, \& Bakare, 2017; OECD, 2016).

To reduce the demand-supply gap, the Malaysian Government has taken numerous measures to support human capital development by providing up-skilling and re-training programmes such as those initiated by Technical and Vocational Education Training (TVET), Institute Kemahiran Belia Negara (IKBN), Dusun Tua and Institute Latihan Perindustrian (ILP). Furthermore, the Ministry of Human Resources in Malaysia also initiated the Human Resource Development Fund (HRDF) in 1993, which was then governed by the Pembangunan Sumber Manusia Bhd Act 2001 (PSBM Act 2001) to enforce training at workplace especially in the manufacturing industry. As the 4IR is not only characterised by a range of new technologies that are fusing the physical, digital and biological worlds and impacting all disciplines, economies and industries, it also calls for a revolution in the way we work to facilitate adjustment to the labour market flexibility. Even more challenging is a higher demand for soft skills by employers to perform jobs in the future. Hence, the role of employers in this new age is to help employees enhance their soft skills to meet the demands of the industry (World Economic Forum (WEF), 2016).

Workers increased their productivity by learning new skills and perfecting old ones which led to better firm performance (Becker, 1993). Because of the greater demand for soft skills, employers believe that investment in re-skilling current employees is necessary to manage their human resources in the long term rather than hiring more short-term workers (WEF, 2016). As a result of the changes in economic structures and employers' response to these changes, there is a critical need for employers to investigate the impacts of soft skills training and development to equip their employees with essential skills to perform the required tasks. Also needed is an assessment of the impact of these soft skills training and development programmes on 
employees' performance and firm's performance. All training programmes incurred costs, and while past studies have established the relationship between training and development and performance, most of these studies do not specify the types of skills (Laker \& Powell, 2011). Therefore, this study attempts to fill the gap by focusing on soft skills training and development provided by employers for their employees and how it influences human resource outcomes and organisational performance.

\section{LITERATURE REVIEW}

A workforce fully equipped with the necessary soft skills is needed to meet the higher demand from employers to fuel the recent changes in technology and to sustain firm's competitiveness (WEF, 2016).

\section{$2.1 \quad$ Soft Skills}

Soft skills are defined as skills, abilities and traits pertaining to personality, attitude and behaviour (Moss \& Tilly, 1996 p.253). They are intrapersonal and interpersonal skills which are difficult to observe, quantify and measure (Laker \& Powell, 2011, p111; Ibrahim et al., 2017, p.391). Most commonly referred areas of soft skills are: (i) communication, (ii) critical thinking, creative thinking and problem solving, (iii) moral and professional ethics (iv) teamwork (v) leadership (vi) entrepreneurship and (vii) emotional intelligence (Ibrahim et al., 2017; Ministry of Higher Education (MOHE), 2006). In general, problem-solving, teamwork, communication, adaptability and interpersonal skills are considered the most important skills for employers (Institute of Student Employers (ISE), 2018; Ibrahim et al., 2017). As indicated in WEF (2016) report, employers demand the following top 10 core-related skills by 2020 compared to 2015 :

Table 1: Top 10 Skills Demanded by Employers by 2020 Compared to 2015

\begin{tabular}{clcl}
\hline \hline & \multicolumn{2}{c}{ Skills } & \\
\hline i. & Complex problem-solving skills & i. & Complex problem solving \\
ii. & Critical thinking & ii. & Coordinating with others \\
iii. & Creativity & iii. & People management \\
iv. & People management & iv. & Critical thinking \\
v. & Coordinating with others & v. & Negotiation \\
vi. & Emotional Intelligence & vi. & Quality control \\
vii. & Judgment and Decision making & vii. & Service Orientated \\
viii. & Service Orientation & viii. & Judgment and decision making \\
ix. & Negotiation & ix. & Active listening \\
x. & Cognitive flexibility & x. & Creativity \\
\hline \hline
\end{tabular}

Source: Future of Jobs Report, WEF (2016)

Table 1 shows past important skills, such as quality control and active listening will cease to be so in the future. Employees are expected to possess new skills such as emotional intelligence, critical thinking, creative thinking, judgement making and complex problem solving, which fall into the component of soft skills. 
Employers also look for candidates with good command of English language to contribute to firm's competitiveness (Zainuddin, Pillai, Dumanig, \& Phillip, 2019).

\subsection{Soft Skills Training and Development $(T \& D)$}

Due to today's fast-paced global and technological development, the consensus view is firms should be vigilant in aligning their HRM practices with training a productive and competitive workforce to contribute to organisation's profitability and advantage. Hence, workforce training and development is deemed important (Rahman, Ng, Sambasivan, \& Wong, 2013).

'Training' aims to bridge the gap between the current and the desired performance and needs to match business needs and objectives defined by the organisation (Ludwikowska, 2018). 'Development' is the strategic long-term activity for employees to fulfil the changing organisational goals (Elnaga \& Imran, 2013; Stam \& Molleman, 1999). Rahman and Nas (2013) described 'employee development' as both employee/employer consistently engaging to improve employees' overall effectiveness while the investment is returned in the form of more productive and effective employees.

In the human capital theory, Becker (1993) classifies training into general and specific training. He suggests firms should pay the cost of specific training, as it raises employees' productivity at the firm providing it. The investment might be lost when employee leaves the firm. For general training, employers might not be able to capture any future returns on their investment, employees themselves should pay for the cost.

According to Mishra and Smyth (2015), general training focuses on soft skills complements specific training and enhances firm's performance. In contrast, Grugulis and Vincent (2009) find soft skills and technical skills are not always complementary. However, Kessler and Lülfesmann (2006) suggest that firm can invest in general as well as specific training as both investments have interacting effects.

Soft skills training is important to sustain firm's competitiveness (Ibrahim et al., 2017). Hard skills are taught for job performance. Hard skills training prepares employees on a need-to-know basis and works within a more restricted setting than soft skills training. In contrast, soft skills training provides the good-to-know basis to deal with a more uncertain context (Laker \& Powell, 2011; Botke, Jansen, Khapova, \& Tims, 2018). Transfer of soft skills training can be considered as the most problematic type of training transfer. It would be a waste of effort if trainees failed to use the trained knowledge and skills on the work (Botke et al., 2018).

Soft skills training is typically scattered, insufficient or quasi non-existent in higher education programmes. Employers do not consistently provide soft skills training to their employees for the long-term growth of the organisation (Bertolini \& Goglio, 2017; International Youth Foundation, 2013). In practice, most employers do not give priority to soft skills as benefits of soft skills are difficult to quantify (International Youth Foundation, 2013). This implies that it is necessary to create performance tools to evaluate the quality of the soft skills training. 


\subsection{Training Process: Training Needs, Training Objectives and Training Evaluation}

Sound training and development plans are compelling in increasing employees' productivity and quality of work (Niazi, 2011). Hence, a great deal of attention must be paid to the details of the training plan and the desired outcomes. Past studies show that to align training policy with human capital development, firms should adopt procedures to detect training needs, establish training objectives and conduct training evaluation (Hughey \& Mussnug, 1997; Otuko, Gabriel, \& Douglas, 2013; Úbeda-García, Cortés, Marco-Lajara, \& Zaragoza-Sáez, 2014). According to Kirkpatrick (1996, cited in Iqbal, Maharvi, Malik, \& Khan, 2011, p.275) training objectives, training contents, training material, trainer, training methods, training environment, and training management are training characteristics which affect the outcomes of training evaluation.

\subsubsection{Training Needs}

Training needs are important to maintain employees' skills and competencies to meet future challenges and enhance firm's performance. To cope with the rapidly changing environment and to bridge the skills gap, firms should take a proactive approach in training needs analysis (TNA) to define the problems, plan the expected training, and identify who needs the training (Niazi, 2011). TNA is the proactive process which includes anticipating future needs, identifying the gaps between employees' current competencies and the desired competencies which can be filled by training (Ludwikowska, 2018). Hence, needs assessment provides the guides and serves as a basic for programme design and development, setting of learning objectives, delivery and evaluation (Otuko et al., 2013).

\subsubsection{Training Objectives}

The outcome of TNA is the specification of training objectives, skills and tasks to be trained (Otuko et al., 2013; Kucherov \& Manokhina, 2017; Ibrahim et al., 2017). Effective training and development programmes should aim at improving employees' performance, reduce skills gap and improve organisational performance (Elnaga \& Imran, 2013; Ludwikowska, 2018). The learning objectives should be in line with the company's strategic plan (Úbeda-García et al., 2014) and clearly defined in the strategic training policy (Stam \& Molleman, 1999).

\subsubsection{Training Evaluation}

Training evaluation is an important component of effective training and development (Otuko et al., 2013; Úbeda-García et al., 2014). Its purposes are: to find the relationship between acquired knowledge, transfer of knowledge at the workplace and training, to improve the quality and relevance of training programmes to ensure training effectiveness and cost (Iqbal et al., 2011; Olexová, 2017). The evaluation aspects include: alignment with firm's strategies, training objectives, training content and methodological design, quality of facilitators, skills, and knowledge acquired by trainees and impacts to firm's performance (Iqbal et al., 2011; Kucherov \& Manokhina, 2017; Tharenou, Saks, \& Moore, 2007). Yet, according to Santos and Stuart (2003) for soft skills training, such immediate training evaluation is not practical. Pre and post evaluation procedures are not enough to ensure effective transfer of knowledge and skills acquired to the workplace. A well-developed system of appraisal and personal development planning for pre and post training is needed. 


\subsection{Theoretical Background}

This study adopted the human capital theory and Resource-Based View, to examine the importance of human capital and its development on firm's performance.

\subsubsection{Human Capital Theory}

According to human capital theory, knowledge and people skills are the most important assets in any organisation (Becker, 1993). The theory suggests that individuals and society derive economic benefits from investments in people which take the form of formal education, informal education and on-the-job training. For firms or employees to invest in on-the-job training and development, two types of training are relevant, namely general training and specific training. They differ in their transferability after a job change. General training will affect employees' productivity in all firms while specific training is only applicable to a particular firm. Nowadays employers are more willing to invest in soft skills, particular most in-demand soft skills (Kessler \& Lülfesmann, 2006; Ibrahim et al., 2017). Although there is increasing demand for soft skills by employers, there is still a lack of study whether the employers consider employees' soft skills training as an expense or investment.

\subsubsection{Resource-Based View (RBV)}

Penrose (1959) introduced the concept of Resource-Based View (RBV) to examine how firms create sustainable competitive advantage by looking at their management and deployment of internal resources. Barney (1991) highlighted that the sustained competitive advantage of a firm is based on its Valuable, Rare, Imperfectly imitable and Non-substitutable resources (VRIN). Through its strategic human resource management (SHRM), a firm can sustain its competitive advantage by producing employees with unique inimitable skills who add value to the firm to achieve its operational goals and business performance (Das \& Kodwani, 2018). Recent studies showed that more employers are considering soft skills as sources of sustainable competitive advantage and the demand for soft skills is increasing in 4IR (WEF, 2016). In today's competitive environment, firms are not only managing soft skills as internal sources or capabilities, more importantly, they should be utilised to enhance firm's performance.

\subsection{Formulation of Hypothesis}

Human capital theory considers employees' knowledge and skills as the most important assets of an organisation. Investment in training will affect employees' productivity. Similarly, the Resource-Based View postulated that firm can sustain its competitive advantage by producing employees with unique, inimitable skills to add value to firm through SHRM. In summary, both theories viewed training as an important element resulting in the acquisition of knowledge, skills and ability to achieve desired organisational goals and performance.

Training policy has always been used for studies in firms' learning and performance. Literature shows there is no consensus on how to measure the characteristics of training and suggests it should be planned and long-term oriented to show a positive effect on performance (Barba Aragón, Jiménez Jiménez, \& Sanz Valle, 2013). Taking into account the training and 
development measures used by Úbeda-García et al., (2014), three training processes are proposed, namely training needs, training objectives and training evaluation.

Since the literature indicates that more employers are willing to invest in soft skills in the new age (Kessler \& Lülfesmann, 2006; Ibrahim et al., 2017), there is increasing need to explore whether firms' soft skills T\&D has an impact on organisational effectiveness. This study adapts the framework of Úbeda-García et al., (2014) to examine specifically the implications of soft skills training policy on human resource outcome and firm performance.

\subsubsection{Soft Skills T\&D and Human Resource Outcome}

The past studies attempted to establish an association between HRM practices and employees' performance such as employee competence, behaviour or work performance (Ibrahim et al., 2017; Katou, 2011). Bhal (2015) noted there is a lack of understanding of the emerging trend - a paradigm shift in the importance of the training of soft skills and its contribution to performance improvement. Studies by Barba Aragón et al., (2013) and Chartered Institute of Personnel and Development (CIPD) (2017) showed that investment in general training has real value for an organisation and in some cases, has a greater impact on employee outcomes, such as earnings and job performance than firm-specific training in certain industries and contexts. To explore such a relationship between soft skills training and employee performance in the Malaysian manufacturing industry, the following hypothesis is proposed:

\section{H1: There is a positive relationship between soft skills $T \& D$ and human resource outcome}

\subsubsection{Soft Skills T\&D and Firm Performance}

Emerging research on HRM practices and firm's performance shows that investment in human capital has a positive impact on organisational performance such as improving its productivity and profitability (Katou, 2011; Tharenou et al., 2007). Yet, different arguments reveal that training by itself does not necessarily result in improved company performance (Thang, Quang, \& Buyens, 2010; Kwon, 2019). Hughey and Mussnug (1997) indicated that soft skills training is generally the least effective in terms of tangible gains as most soft skills training is never put into actual practice to realise its benefits. Adults also tend not to acquire new competencies overnight.

Given the above argument, this study examines the impacts of a firm's investment in soft skills $\mathrm{T} \& \mathrm{D}$ which is relatively lacking in the literature. The hypothesis formulated is:

\section{H2: There is a positive relationship between soft skills T\&D and firm performance}

\subsubsection{Human Resource Outcome and Firm Performance}

Previous studies have highlighted the positive linkage between human resource outcome and firm performance and argued that HRM practices affect organisational performance through their effect on employee development such as enhancing their competencies, behaviour, attitude, and performance at work (Cesário \& Chambel, 2017; Katou, 2011). In this study, the effect of human resource outcome on firm performance is to be examined. 
H3: There is a positive relationship between human resource outcome and firm performance

\subsubsection{Mediating Effect of Human Resource Outcome on Soft Skills T\&D and Firm Performance}

It is generally accepted that training and development can improve firm's performance, yet, according to Barba Aragón et al., (2013) and Rahman et al., (2013), the empirical research focusing on training-performance link does not always provide the evidence to support this effect. Some of the past studies highlighted that the relationship between HRM policies and organisational performance was partially mediated by employee attitudes and human capital (Tharenou et al., 2013; Katou, 2011). Since firms may not obtain the expected benefits directly from training, but may benefit through indirect effect from human resource outcome, this study proposes to conduct a test on the following hypothesis for soft skills training and development of firms:

H4: Human resource outcome positively mediates the relationship between soft skills $T \& D$ and firm performance

\subsection{Conceptual Framework}

Drawing on the literature described and the related theoretical framework, the hypotheses are developed and graphically represented in Figure 1.

The model is represented by one exogenous construct (soft skills training and development (T\&D)) and two endogenous constructs (human resource outcome (HRO) and firm performance (FP)). Training needs (TN), training objectives (TO) and training evaluation (TE) constructs, are the three dimensions of T\&D. From the theoretical / conceptual point of view, this model is simplified by using single dimension of higher-order modelling (HOM) study. HOM summarises the lower-order components (LOCs) of TN, TO and TE into a single multi-dimensional HOC of T\&D.

In this study, T\&D is a reflective construct as T\&D related to employees' acquiring of knowledge and skills is characterised by training process of identifying TN, formulating TO and TE. The impact of training policy on HRO and FP is inconclusive. To a large extent, training policy will have a different orientation characterised by firms' training process (Úbeda-García et al., 2014). Similarly, according to Kirkpatrick (1996, cited in Iqbal et al., 2011, p.275) these training variables are training characteristics of the training policy. 
Figure 1: The Proposed Conceptual Framework of the Study

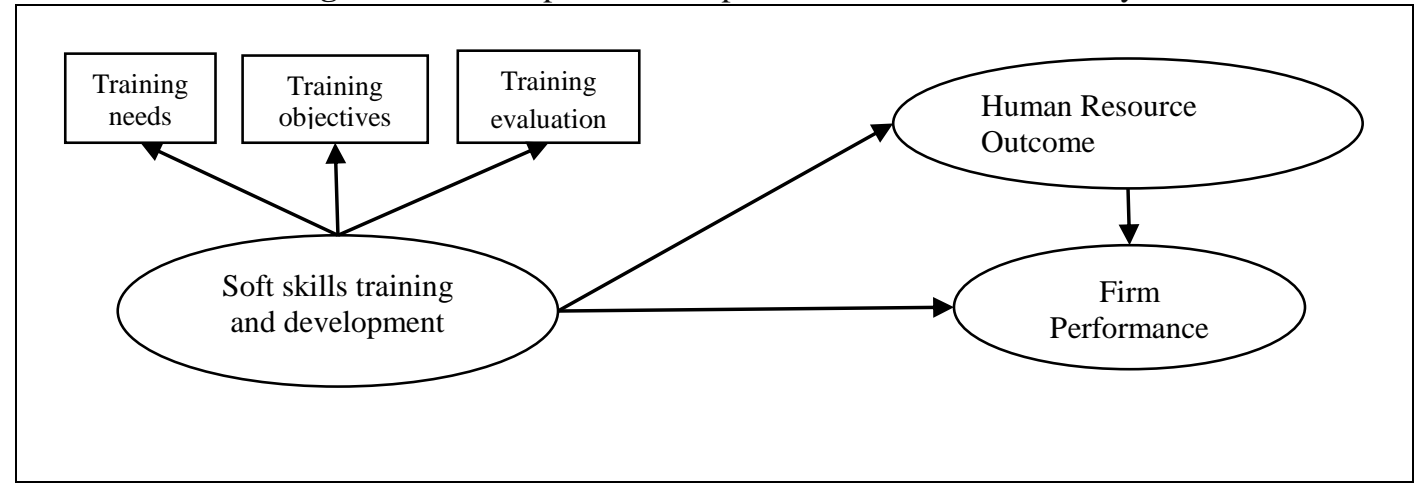

\section{METHODOLOGY}

\subsection{Sample and Procedure}

This study focused on the manufacturing industry in Malaysia. Targeted respondents are manufacturing firms located within the industrial estates in the states of Selangor, Johor, Penang and Perak. The sampling frame is constructed from the list of manufacturers from the Malaysian Investment Development Authority (MIDA).

Table 2 shows the sample size recommendations in PLS-SEM for a statistical power of $80 \%$ as suggested by Cohen (1992).

Table 2: Sample Size Recommendation in PLS-SEM for a Statistical Power of 80\%

\begin{tabular}{|c|c|c|c|c|c|c|c|c|c|c|c|c|}
\hline \multirow{2}{*}{$\begin{array}{l}\text { Maximum number } \\
\text { of arrows pointing } \\
\text { to a construct } \\
\text { (Number of } \\
\text { independent } \\
\text { variables) }\end{array}$} & \multicolumn{12}{|c|}{ Significance level } \\
\hline & \multicolumn{4}{|c|}{ Minimum $\mathrm{R}^{2}$} & \multicolumn{4}{|c|}{ Minimum $\mathrm{R}^{2}$} & \multicolumn{4}{|c|}{ Minimum $\mathrm{R}^{2}$} \\
\hline & 0.1 & 0.25 & 0.50 & 0.75 & 0.1 & 0.25 & 0.50 & 0.75 & 0.1 & 0.25 & 0.50 & 0.75 \\
\hline 2 & 72 & 26 & 11 & 7 & 90 & 33 & 14 & 8 & 130 & 47 & 19 & 10 \\
\hline 3 & 83 & 30 & 13 & 8 & 103 & 37 & 16 & 9 & 145 & 53 & 22 & 12 \\
\hline 4 & 92 & 34 & 15 & 9 & 113 & 41 & 18 & 11 & 158 & 58 & 24 & 14 \\
\hline 5 & 99 & 37 & 17 & 10 & 122 & 45 & 20 & 12 & 169 & 62 & 26 & 15 \\
\hline 6 & 106 & 40 & 18 & 12 & 130 & 48 & 21 & 13 & 179 & 66 & 28 & 16 \\
\hline 7 & 112 & 42 & 20 & 13 & 137 & 51 & 23 & 14 & 188 & 69 & 30 & 18 \\
\hline 8 & 118 & 45 & 21 & 14 & 144 & 54 & 24 & 15 & 196 & 73 & 32 & 19 \\
\hline 9 & 124 & 47 & 22 & 15 & 150 & 56 & 26 & 16 & 204 & 76 & 34 & 20 \\
\hline 10 & 129 & 49 & 24 & 16 & 156 & 59 & 27 & 18 & 212 & 79 & 35 & 21 \\
\hline
\end{tabular}

Source: Cohen (1992): A power Primer. Psychological Bulletin 112:155-159

In this study, two arrows are pointing at the endogenous construct of $F P$, to detect $\mathrm{R}^{2}$ value of 0.1 for the significance level of 1\%, as suggested by Cohen (1992), the minimum sample size is 130 . 
According to Sekaran (2013), any sample size larger than 30 and less than 500 are appropriate for most research. However, past studies had shown that the response rate from manufacturing industry was generally low, for instance, in studies of Rasul, Rauf, Mansor, Yasin and Mahamod (2013) and Wan Abdullah (1994) only 107 and 60 employers from manufacturing industry participated. To be able to generalise and draw meaningful conclusions from the research findings, the simple random sampling technique was used in collecting data via questionnaire from 1,790 firms, i.e. $40 \%$ of the population as shown in Table 3:

Table 3: Computation of $40 \%$ of the Population

\begin{tabular}{cc}
\hline \hline State & No. of targeted respondents \\
\hline Selangor & $2,036 \times 40 \%=814$ \\
Johore & $1,324 \times 40 \%=530$ \\
Penang & $827 \times 40 \%=330$ \\
Perak & $291 \times 40 \%=116$ \\
Total & $\mathbf{1 , 7 9 0}$ \\
\hline
\end{tabular}

A total of 1,790 questionnaires were mailed to the human resource department of the selected manufacturing firms. After extensive follow-ups through emails and phone calls, a total of 199 questionnaires were returned, and this represented a response rate of $11.12 \%$. The questionnaires were completed by the Manager / Senior Manager / Director (48.70\%), Executive (39.70\%), and others $(11.5 \%)$. The demographic profiles of the firms are presented in Table 4 below:

Table 4: Demographic Profiles of the Firms

\begin{tabular}{cllc}
\hline \hline Characteristics & \multicolumn{1}{c}{ Categories } & Frequency & \% \\
\hline State & Selangor & 33 & 16.60 \\
& Johore & 37 & 18.60 \\
& Penang & 91 & 45.70 \\
& Perak & 38 & 19.10 \\
& Total & $\mathbf{1 9 9}$ & $\mathbf{1 0 0 . 0 0}$ \\
\hline \multirow{2}{*}{ Sub-sector } & Electrical \& electronics & 58 & 29.15 \\
& Food, beverage and tobacco & 19 & 9.55 \\
& Non-metallic, mineral products, basic & 27 & 13.57 \\
& metal \& fabricated metal products & & 15.06 \\
& Petroleum chemical, rubber \& plastic & 30 & 4.02 \\
& Textile, weaving, apparel \& leather & 8 & 17.59 \\
& Transport equipment \& other & 35 & 10.55 \\
& manufacturers & & 0.50 \\
& Wood products, furniture, paper & 21 & $\mathbf{1 0 0 . 0 0}$ \\
\hline & products \& printing & 1 & 27.10 \\
& Missing data & $\mathbf{1 9 9}$ & 9.00 \\
& Total & 54 & 8.00 \\
& $<100$ & 73 & 2.00 \\
& $100-400$ & 18 & \\
& $401-700$ & 16 & 4 \\
& $701-1000$ & & \\
& $1001-1300$ & &
\end{tabular}




\begin{tabular}{clll} 
& $>1300$ & 34 & 17.10 \\
Status of the & Total & $\mathbf{1 9 9}$ & $\mathbf{1 0 0 . 0 0}$ \\
company & MNC & 103 & 51.80 \\
& Local & 96 & 48.20 \\
& Total & $\mathbf{1 9 9}$ & $\mathbf{1 0 0 . 0 0}$ \\
No. of years & & & \\
Organisation & & 7 & 3.50 \\
exists & 5 5 years & 36 & 18.10 \\
& 5-15 years & 62 & 31.20 \\
& 16-25 years & 46 & 23.10 \\
& 26-35 years & 48 & 24.10 \\
& $>35$ years & $\mathbf{1 9 9}$ & $\mathbf{1 0 0 . 0 0}$ \\
\hline & Total & &
\end{tabular}

\subsection{Measures}

\subsubsection{Soft Skills Training \& Development $(T \& D)$}

The measurements of the three dimensions of T\&D, TN, TO \& TE were adapted from the work of Úbeda-García et al., (2014). They were measured with five items each on a 1-5 Likert-type scale where (1) indicates strongly disagree and (5) strongly agree.

\subsubsection{Human Resource Outcome (HRO)}

The measurements for HRO were adapted from the studies of Katou (2011) and Úbeda-García et. al., (2014). HRO was classified as (i) soft skills competence; (ii) attitude (working attitude, satisfaction); and (iii) behaviour (face challenges, participation).

The types of soft skills adapted from Malaysia Soft Skills Scale (My3S) were used by MQA to assess undergraduates during entry and exit points. These soft skills are: (i) communication, (ii) critical thinking, creative thinking and problem solving, (iii) moral and professional ethics, (iv) teamwork (v) leadership, and (vi) decision making. Emotional Intelligence and language skills were added in the study as according to Bhal (2015), soft skills are closely connected with the English language while emotional intelligence alone encompasses soft skills. In response to internationalisation and the diverse needs of multinational companies, Malaysians have to use more languages to deal with foreign managers, employees, suppliers, customers, distributors, etc. Bahasa Malaysia is Malaysia's national language while English and Chinese are the second languages of communication in Malaysia.

\subsubsection{Firm Performance (FP)}

Measurements for FP were focused on both financial and non-financial performance as adapted from the studies of Katou (2011) and Úbeda-García et.al., (2014). In this study, FP was denoted by improvement in profitability, product quality, service quality, competitiveness, capacity to meet future opportunities and challenges, the ability to reduce production costs and innovativeness of the organisation. Since the expected outcome is improved FP, "enhance" is used to imply the effects from soft skills T\&D. 
All items in HRO and FP are measured on a 5-point Likert scale where (1) indicates very low level and (5) indicates very high level.

\section{RESULTS AND DISCUSSION}

The model was analysed using Structural Equations Models (SEM), with the Partial Least Squares (PLS) technique. This included path modelling and bootstrapping method.

\subsection{Results}

\subsubsection{Assessment of the Measurement Model}

The convergent validity which measures the degree to which multiple items measuring the same concepts were in agreement was first tested. As suggested by Hair, Black, Babin and Anderson (2010), the factor loadings, composite reliability (CR) and average variance extracted (AVE) were used to assess convergence validity. The loadings for items exceeding the recommended value of 0.7 (Hair et al., 2010) were retained (Table 5). Items with loading less than 0.70 were removed. CR values shown in Table 5 depict the degree to which the construct indicators indicated the latent construct ranging from 0.881 to 0.932 , which exceeded the recommended value of 0.7 (Hair et al., 2010). The AVE values were in the range of 0.598 to 0.663 which were higher than the recommended value 0.50 , the values were considered acceptable (Hair et al., 2010).

Table 5: Results of the Measurement Model

\begin{tabular}{|c|c|c|c|c|c|}
\hline $\begin{array}{c}\text { Constructs \& description of } \\
\text { items }\end{array}$ & Indicator & $\begin{array}{c}\text { Factor } \\
\text { Loading } \\
(\lambda) \\
(>\mathbf{0 . 7 0})^{\mathrm{a}}\end{array}$ & $\begin{array}{c}\alpha \\
\text { Cronbach } \\
(>0.70)^{\mathrm{a}}\end{array}$ & $\begin{array}{c}\mathbf{C R} \\
(>\mathbf{0 . 7 0})^{\mathrm{a}}\end{array}$ & $\underset{(>\mathbf{0 . 5 0})^{\mathrm{a}}}{\mathrm{AVE}}$ \\
\hline Training \& Development & T\&D & & 0.911 & 0.924 & 0.636 \\
\hline Training Needs & $\mathrm{TN}$ & 0.846 & 0.819 & 0.881 & 0.649 \\
\hline $\begin{array}{l}\text { Diagnose training needs for Soft } \\
\text { skills }\end{array}$ & TN1 & 0.760 & & & \\
\hline $\begin{array}{l}\text { Identify areas of soft skills } \\
\text { employees have }\end{array}$ & TN2 & 0.869 & & & \\
\hline $\begin{array}{l}\text { Identify soft skills for future } \\
\text { improvement }\end{array}$ & TN3 & 0.811 & & & \\
\hline $\begin{array}{l}\text { Training requests expressed by } \\
\text { staff to improve soft skills }\end{array}$ & TN4 & $0.566^{\mathrm{b}}$ & & & \\
\hline Identify soft skills for current job & TN5 & 0.778 & & & \\
\hline Training Objectives & TO & 0.875 & 0.826 & 0.885 & 0.657 \\
\hline Adapt to anticipated changes & TO1 & 0.782 & & & \\
\hline Increase job satisfaction & TO2 & 0.849 & & & \\
\hline Close soft skills gap & TO3 & 0.822 & & & \\
\hline $\begin{array}{l}\text { Greater involvement in the } \\
\text { organisation }\end{array}$ & TO4 & 0.788 & & & \\
\hline Enhance employees' morale & TO5 & $0.637^{\mathrm{b}}$ & & & \\
\hline
\end{tabular}




\begin{tabular}{|c|c|c|c|c|c|}
\hline Training Evaluation & TE & 0.899 & 0.839 & 0.886 & 0.608 \\
\hline $\begin{array}{l}\text { Contribution to long term } \\
\text { development of business }\end{array}$ & TE1 & 0.743 & & & \\
\hline $\begin{array}{l}\text { Impact on employees' } \\
\text { performance }\end{array}$ & TE2 & 0.809 & & & \\
\hline Application of soft skills acquired & TE3 & 0.759 & & & \\
\hline Soft skills trained meet org need & TE4 & 0.804 & & & \\
\hline Impact on morale of employees & TE5 & 0.782 & & & \\
\hline \multicolumn{6}{|l|}{ Human Resource Outcome } \\
\hline Soft Skills Competence & & & & & \\
\hline Team work & HRO1.1 & $0.596^{\mathrm{b}}$ & & & \\
\hline communication & HRO1.2 & 0.745 & 0.916 & 0.930 & 0.598 \\
\hline Leadership & HRO1.3 & $0.690^{\mathrm{b}}$ & & & \\
\hline $\begin{array}{l}\text { Critical, creative thinking \& } \\
\text { problem solving skills }\end{array}$ & HRO1.4 & 0.761 & & & \\
\hline Language skills & HRO1.5 & $0.672^{\mathrm{b}}$ & & & \\
\hline Decision making & HRO1.6 & 0.784 & & & \\
\hline Emotional Intelligence & HRO1.7 & 0.748 & & & \\
\hline Moral \& Ethics & HRO1.8 & 0.740 & & & \\
\hline \multicolumn{6}{|l|}{ Behaviour } \\
\hline $\begin{array}{l}\text { Achieve higher work satisfaction } \\
\text { level }\end{array}$ & $\mathrm{HRO} 2.0$ & 0.769 & & & \\
\hline $\begin{array}{l}\text { Achieve higher participation } \\
\text { level }\end{array}$ & HRO3.0 & 0.761 & & & \\
\hline \multicolumn{6}{|l|}{ Attitude } \\
\hline Improve work attitude & HRO4.0 & 0.865 & & & \\
\hline $\begin{array}{l}\text { Improve ability to face } \\
\text { challenges }\end{array}$ & HRO5.0 & 0.777 & & & \\
\hline Firm Performance & & & 0.915 & 0.932 & 0.663 \\
\hline Enhance org's profitability & FP1 & 0.741 & & & \\
\hline Enhance product quality & FP2 & 0.767 & & & \\
\hline Enhance quality of service & FP3 & 0.811 & & & \\
\hline Enhance org's competitiveness & FP4 & 0.880 & & & \\
\hline $\begin{array}{l}\text { Enhance org's capacity to meet } \\
\text { challenges and future } \\
\text { opportunities }\end{array}$ & FP5 & 0.887 & & & \\
\hline $\begin{array}{l}\text { Enhance ability to reduce } \\
\text { production costs }\end{array}$ & FP6 & 0.829 & & & \\
\hline Enhance innovativeness & FP7 & 0.775 & & & \\
\hline
\end{tabular}

Notes: $\quad{ }^{a}$ Indicates an acceptable level of reliability and validity

${ }^{\mathrm{b}}$ Indicates removal item as loading $(\lambda)$ less than 0.70 .

\subsubsection{Discriminant Validity of Constructs}

The discriminant validity describes the extent to which each construct is distinct from one another (Chin, 1998). It can be examined by comparing the squared correlations between the constructs and the variance extracted for a construct (Fornell \& Larcker, 1981). As shown in Table 6, the squared correlations for each construct were less than the AVE by the indicators measuring that construct. This result indicates adequate discriminant validity. 
Table 6: Discriminant Validity Using Fornell and Larcker Criterion

\begin{tabular}{lllc}
\hline \hline & $\mathbf{1}$ & $\mathbf{2}$ & $\mathbf{3}$ \\
\hline 1 FP & $\mathbf{0 . 8 1 4}$ & & \\
2 HRO & 0.767 & $\mathbf{0 . 7 7 3}$ & \\
T\&D & 0.279 & 0.359 & $\mathbf{0 . 6 9 7}$ \\
\hline \hline
\end{tabular}

Note: diagonals are the AVE while the off-diagonals are the squared correlations

\subsubsection{Assessment of Structural Model}

The structural model indicates the causal relationships among the constructs in the model which includes the estimates of path coefficients and $\mathrm{R}^{2}$ value, which determine the predictive power of the model. Together, the $\mathrm{R}^{2}$ and path coefficients indicate how well the data support the hypothesised model (Chin, 1998). As shown in Figure 2, and Table 7, two out of three hypotheses are supported. T\&D $(\beta=0.359, \mathrm{p}<0.01)$ is positively related to HRO, while the coefficient of determination, $\mathrm{R}^{2}$ is 0.129 for HRO. This means that $\mathrm{T} \& \mathrm{D}$ explains $12.9 \%$ of the variance in HRO. HRO $(\beta=0.766, \mathrm{p}<0.01)$ is also positively related to FP and moderately explains $58.9 \%$ of the variance in FP. Thus, $\mathrm{H} 1$ and $\mathrm{H} 3$ are supported. In contrast, $\mathrm{H} 2$ is not supported as the influence of $\mathrm{T} \& \mathrm{D}$ on $\mathrm{FP}(\beta=0.003, \mathrm{p}>0.01)$ is not significant. In addition, to assess the significance of the path coefficients and to evaluate their values, a bootstrapping procedure with 5,000 subsamples was used. The assessment of mediating effects was then assessed. The results of the bootstrapping are presented in Table 7.

Figure 2: Structural Model with Indicators and Path Coefficients

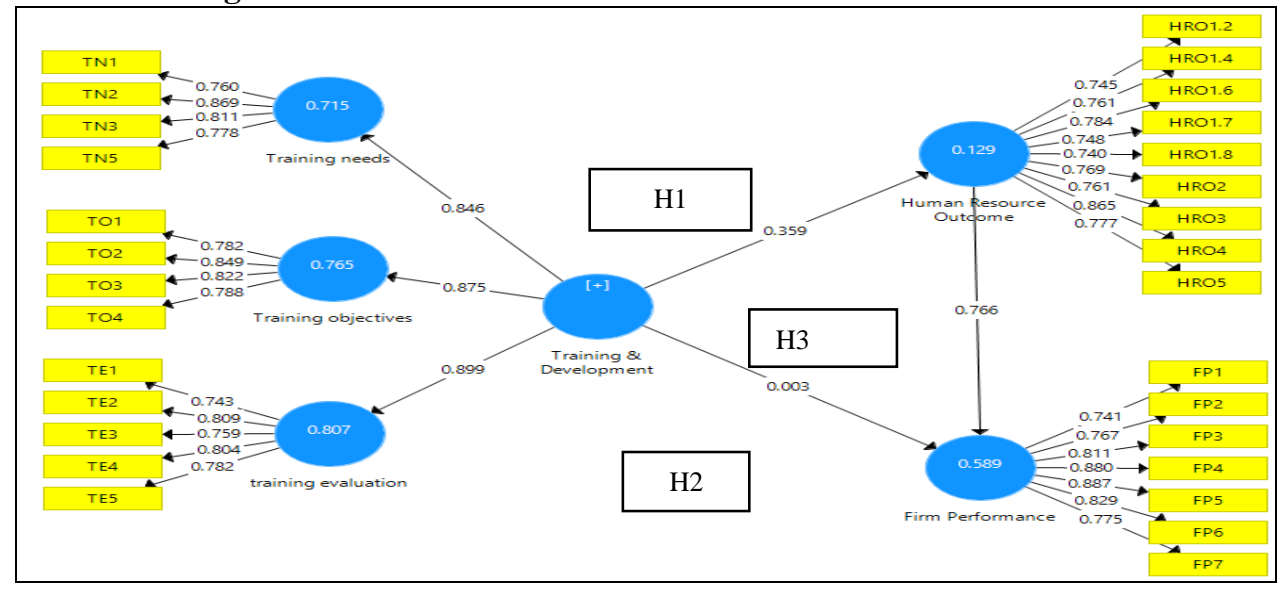

Table 7 shows that all path coefficients for hierarchical models are significant at 0.01 level. As shown in Table 5, the CR value of the second-order construct T\&D was 0.924 suggesting a satisfactory level of reliability for the first-order constructs with the corresponding second-order construct. 
Table 7: Structural Model Results (Excluding mediation)

\begin{tabular}{lccccc}
\hline \hline \multicolumn{1}{c}{ Hypothesis } & $\begin{array}{c}\text { Suggested } \\
\text { effect }\end{array}$ & $\begin{array}{c}\text { Path } \\
\text { coefficients B }\end{array}$ & t-value & p-value & Results \\
\hline H1: T\&D -> HRO & + & 0.359 & 5.370 & 0.000 & Supported \\
H2: T\&D ->FP & + & 0.003 & 0.075 & 0.940 & Not supported \\
H3: HRO ->FP & + & 0.766 & 23.633 & 0.000 & Supported \\
\hline \hline
\end{tabular}

Table 8: Indirect Effects, Total Effects and VAF Value

\begin{tabular}{lccccc}
\hline \hline \multicolumn{1}{c}{ Path } & $\begin{array}{c}\text { Indirect } \\
\text { effect }\end{array}$ & T-Statistics & p value & Total effect & $\begin{array}{c}\text { VAF } \\
\text { Indirect effect / } \\
\text { Total effect) }\end{array}$ \\
\hline $\begin{array}{l}\text { T\&D->HRO } \\
\text { T\&D -> FP }\end{array}$ & & & & & \\
$\begin{array}{l}\text { T\&D->HRO- } \\
\text { >FP }\end{array}$ & 0.275 & 4.947 & 0.000 & 0.278 & 0.990 \\
\hline \hline
\end{tabular}

In PLS path model, T\&D construct has a direct effect on HRO but T\&D does not have a direct effect on FP. Even though T\&D does not have a direct effect on FP, the relationship between these two constructs is mediated by HRO, for which the total effect is estimated by summing up direct and indirect effects. The mediation analysis results are shown in Table 8. The indirect effect of the independent variable is significant. This shows that T\&D is a key strategy to increase HRO and that, through this effect, T\&D affects FP. Finally, the strength of mediation computed via variance accounted for (VAF) is assessed. Table 8 shows that $99 \%$ of the effect of T\&D on FP is explained via HRO. Since the value of VAF is larger than $80 \%$, this suggests HRO has a full mediating role between T\&D and FP (Hair, Hult, Ringle, \& Sarstedt, 2014).

\subsection{Discussion}

\subsubsection{T\&D and its Associated Variables}

As reviewed earlier, $\mathrm{T} \& \mathrm{D}$ is characterised by three training variables (TN, TO, and TE). As shown in Table 5, TN4 (training requests expressed by staff to improve their soft skills), TO5 (training seeks to enhance employees' morale), HRO1.1, HRO1.3 and HRO1.5 (employees improve soft skills competence in teamwork, leadership and language skills) were removed. Removal of these insignificant indicators implies they lack absolute contribution (importance) to their respective reflective constructs (TN, TO, HRO) or lack of support for the notions of the reflective constructs assigned (Roni, Djajadikerta, \& Ahmad, 2015).

T\&D has strong relationships with its LOC, TE $(\lambda=0.899)$. Among the five items used to constitute this construct, TE2 (impact on employees' performance) is a valuable indicator of TE $(\lambda=0.809)$ (Table 5). This indicates that for achievement of best results in soft skills T\&D, it is essential for firms to ensure T\&D has an impact on employees' performance (TE2).

TO has a factor loading of 0.875 . On examining the loadings of its indicators, items TO2 (increase job satisfaction) and TO3 (close soft skills gap) are key indicators of TO (Table 5). This finding supports the recommendation of past researchers that training objectives should be 
focused on developing the competencies of employees in line with company's strategic plan, business needs, skill gap reduction target and organisational performance improvement (Ibrahim et al., 2017; Ludwikowska, 2018).

TN has a factor loading of 0.846 . Its indicators with a high loading are TN2 $(\lambda=0.869)$ and TN3 $(\lambda=0.811)$ (Table 5). This shows that to achieve best results of soft skills T\&D on HRO and FP, firms are required to conduct TNA to identify the areas of soft skills employees already have (TN2) and soft skills for future improvement (TN3). These findings support the study of Ludwikowska (2018) where TNA is the proactive process which includes anticipating future needs and identifying the gaps between employees' current competencies and the desired competencies which can be filled by training.

\subsubsection{T\&D, HRO and FP}

This study suggests that soft skills T\&D of firms explicitly and directly influences HRO and indirectly influences FP of the firms through the mediating effect of HRO. The analysis reveals the following:

\subsubsection{Soft Skills T\&D and HRO}

Firms' soft skills T\&D has a positive and significant relationship with HRO. This finding is congruent with previous studies (Katou, 2011; Ibrahim et al., 2017). The HRO includes improvement in employees' soft skills competencies, behaviour and attitude. These findings provide more evidence of the importance of soft skills T\&D to firm's HRO.

\subsubsection{Soft Skills T\&D and FP}

Soft skills T\&D of firms was posited to have a positive relationship with FP. However, this hypothesis was not supported. This result is consistent with the study of Barba Aragón et al., (2013). As had been reviewed in past studies, training by itself need not necessarily improve a company's performance. The likely explanations for such an effect on FP could be due to lack of assessment on the effectiveness of training at the organisational level (Tharenou et al., 2007), or training is at its initial level does not provide immediate effect on FP (Kwon, 2019), lack of significant / transfer of soft skills acquired from training to the job (Laker \& Powell, 2011); adult trainees do not tend to acquire new competencies overnight (Hughey \& Mussnug, 1997).

\subsubsection{HRO and FP}

The study also found evidence of a positive relationship between HRO and FP. This finding provides empirical evidence that soft skills acquired by employees through the soft skills T\&D shows effects on FP (Cesário \& Chambel, 2017; Katou, 2011; Barba Aragón et al., 2013; Rahman et al., 2013). It also provides support to the human capital theory and RBV that employees' soft skills acquired through T\&D enhance firms' productivity and competitiveness. Hence, firms should consider continuing to help employees to enhance their soft skills. 


\subsubsection{Mediating Effect in the Model}

The analysis of mediating effect shows that HRO has a significant indirect effect on FP, through T\&D impact, which in turn leads to higher FP. In other words, these findings suggest soft skills T\&D is a key strategy to increase HRO in the aspects of soft skill competencies, behaviour and attitude, and through this effect, soft skills may affect FP. The VAF as shown in Table 8 has very large outcomes of above $80 \%$. This suggests HRO has a full mediating effect on soft skills T\&D and FP. This implies that employee who receives T\&D may lead to higher HRO which ultimately results in increased FP. This finding supports the work of Katou (2011) and Barba Aragón et al., (2013).

\section{CONCLUSION}

This study aims to evaluate soft skills T\&D and its influence on human resource outcome and firm performance. The findings showed that soft skills $T \& D$ contributed significantly to human resource outcome to achieve firm performance but did not directly influence firm performance. In other words, human resource outcome is mediating the relationship between soft skills T\&D and firm performance. This result suggested that the direct value of soft skills T\&D is somehow lacking as it did not provide an immediate impact on a firm performance. However, firms should continue to invest in soft skills T\&D as soft skills cannot be learned in a day, and immediate application of soft skills acquired through training is less likely. Moreover, firms should design an appropriate evaluation system and approach for soft skills T\&D, as training evaluation is the most important training phase among the three training phases.

The present research has several theoretical implications. First, human capital theory is enriched by the results showing firm improved its performance from the general training of employees' competencies in soft skills, behaviour and attitude. Second, the findings also provide significant empirical support for RBV that through firm's SHRM, it can sustain its competitive advantage by producing employees with unique inimitable skills who add value to the firm to achieve its operational goals and business performance

This study, along with its contribution to theory, offers three substantial practical implications for soft skills T\&D practice. First, the higher demand for soft skills in the new age shows T\&D of soft skills is critical to firms' success and competitiveness. Second, firms should conduct appropriate training phases to study soft skills needed (current and future), and the existing employees' competencies. Finally, this study provides useful guidelines for the study of soft skills T\&D in other industries, as it supports the value in increasing human resource outcome, which leads to firm performance. This implies that firms should allocate resources efficiently and effectively to T\&D to help employees improve their soft skills.

Despite the contributions, the data for this study were collected from manufacturing industry only. It would be of great interest to include data from more industries and to compare the results obtained in this study from manufacturing industry with other industry such as service sector. Moreover, the service sector is traditionally seen as a heterogeneous sector, comprising diverse areas such as financial companies, retailing operations, transport operations and hospitality. 
The above limitation in this study may be the new path proposed for future researcher to consider replicating this research using samples from other industries, to confirm the findings of soft skills T\&D in enhancing human resource outcome in aspect of competencies, behaviour and attitude, and through this effect, soft skills T\&D may affect firm performance. In addition, there is a general recognition in the literature of a lack of transfer of soft skills acquired through training to the workplace. It would be considered as waste of training resources if skills acquired were not put in use at the workplace. As such, future research aiming at enhancing the transfer of soft skills and knowledge acquired from T\&D to the trainees' workplace is suggested.

\section{ACKNOWLEDGEMENT}

The authors would like to thank the reviewers who have provided comments and suggestions to improve the manuscript.

\section{REFERENCES}

Aulbur, W., Arvind, C. J. \& Bigghe, R. (2016). Skill Development for Industry 4.0 (White Paper). Federation of Indian Chambers of Commerce and Industry (FICCI), \& Roland Berger (RB). Retrieved from http://www.globalskillsummit.com/Whitepaper-Summary.pdf

Barba Aragón, M.I., Jiménez Jiménez, D., \& Sans Valle, R. (2013). Training and performance: The mediating role of organisational learning. Business Research Quarterly, 17(3), 161173.

Barney, J. (1991). Firm resources and sustained competitive advantage. Journal of Management, 17(1), 99-120.

Becker, G. S. (1993). Human Capital A theoretical and empirical analysis, with special reference to education ( $3^{\text {rd }}$ ed.). Chicago: University of Chicago Press.

Bertolini, S. \& Goglio, V. (2017). The demand for qualified personnel: a case study on Northern Italy. Higher Education, Skills and Work-Based Learning 7(1), 51-69.

Bhal, R. S. (2015). Training in soft skills and its importance. International Journal Management and Social Sciences Research, 4(5), 76-81.

Botke, J. A., Jansen, P. G. W., Khapova, S. N., \& Tims, M. (2018). Work factors influencing the transfer stages of soft skills training: A literature review. Educational Research Review 24, 130-147.

Cesário, F., \& Chambel, M. J. (2017). A previous trainee experience: does it matter for retention of young graduates? International Journal of Organisational Analysis, 25(2), 270-281.

Chin, W. W. (1998). The partial least squares approach to structural equation modeling. Modern Methods for Business Research, 295(2), 295-336.

Chartered Institute of Personnel and Development (CIPD). (2017). Human Capital Theory: assessing the evidence for the value and importance of people to organisational success. Retrieved from https://www.cipd.co.uk/Images/human-capital-theory-assessing-theevidence_tcm18-22292.pdf

Cohen, J. (1992). A power primer. Psychological Bulletin, 112, 155-159.

Das, R., \& Kodwani, A. D. (2018). Strategic human resource management: a power based critique. Benchmarking: An International Journal, 25(4), 1213-1231. 
Department of Statistics, Malaysia (DOSM) (2019). Employed Persons by Industry, Malaysia, 1982-2019. Labour Force Survey (LFS) Time Series Statistics by industry, 1982-2019. Retrieved from https://www.dosm.gov.my/v1/index.php?r=column/ctimeseries\&menu_ id=bnk3bk0wTTkxOXVHaVg3SUFDMIBUUT09

Economist Corporate Network (2016). Skills 4.0 How CEOs Shape the Future of Work in Asia. Retrieved from https://www.hays.co.jp/documents/276785/0/Skills+4.0+How+CEOs+ shape+the+future+of+work+in+Asia+ECN.pdf/a4072bed-69c4-e674-934b-b62aa1102 $6 \mathrm{~d} 4 ? \mathrm{t}=1582185785452$

Economic Planning Unit (2020). Second Malaysia Plan, 1971-1975. Chapter 7 Employment by sector, West Malaysia 1965-1970. Retrieved from https://www.epu.gov.my /en/economic-developments/development-plans/rmk/second-malaysia-plan-1971-1975

Elnaga, A., \& Imran, A. (2013). The effect of training on employee performance. European Journal of Business and Management, 5(4), 137-147.

Fornell, C., \& Larcker, D. F. (1981). Evaluating structural equation models with unobservable variables and measurement error. Journal of Marketing Research 18(1), 39-50.

Grugulis, I., \& Vincent, S. (2009). Whose skill is it anyway? Soft skills and polarization. Work, Employment \& Society, 23(4), 597-615.

Hair, J. F., Black, W. C., Babin B. J., \& Anderson, R. E. (2010). Multivariate Data Analysis (7 $^{\text {th }}$ ed.). Upper Saddle River, New Jersey: Prentice Hall.

Hair, J. F. Jr., Hult, G. T. M., Ringle, C. M., \& Sarstedt, M. (2014). A Priemer on Partial Least Squares Structural Equation Modeling (PLS-SEM). California: SAGE publications.

Hughey, A. W., \& Mussnug, K. J. (1997). Designing effective employee Programmes. Training for Quality, 5(2), 52-57.

Ibrahim, R., Boerhannoeddin, A., \& Bakare, K. K. (2017). The effect of soft skills and training methodology on employee performance. European Journal of Training and Development, 41(4), 388-406.

International Youth Foundation (2013). Getting Youth in the Door: Defining Soft Skills Requirements for Entry-Level Service Sector Jobs. Retrieved from https://www.iyfnet.org/sites/default/files/library/Getting_Youth_In_The_Door_Soft_Ski 1ls_Report.pdf

Iqbal, M. Z., Maharvi, M. W., Malik, S. A., \& Khan, M. M. (2011). An empirical analysis of the relationship between characteristics and formative evaluation of training. International Business Research, 4(1), 273-286.

Institute of Student Employers (ISE) (2018). The Global Skills Gap in the $21^{\text {st }}$ Century. Retrieved from http://info.qs.com/rs/335-VIN535/images/The\%20Global\%20Skills\%20Gap\%2021st\%20Century.pdf

Katou, A. A. (2011). Test of a causal human resource management - performance linkage model: evidence from the Greek manufacturing sector. International Journal of Business Science and Applied Management, 6(1), 17-29.

Kessler, A. S., \& Lülfesmann (2006). The Theory of Human Capital revisited: on the interaction of general and specific investments. The Economic Journal, 116(October), 903-923.

Kucherov, D., \& Manokhina, D. (2017). Evaluation of training programs in Russian manufacturing companies. European Journal of Training and Development, 41(2), 119143.

Kwon, K. (2019). The long-term effect of training and development investment on financial performance in Korean companies. International Journal of Manpower, 40(6), 10921109. 
Laker, D. R., \& Powell, J. L. (2011). The differences between hard and soft skills and their relative impact on training transfer. Human Resource Development Quarterly, 22(1), 111-122.

Ludwikowska, K. (2018). The effectiveness of training needs analysis and its relation to employee efficiency. Wroclaw University of Science and Technology No. 77. doi:10.21008/j.0239-9415.2018.077.11

Mishra, V., \& Smyth, R. (2015). Workplace policies and training in China: evidence from Matched Employee-Employer Data. International Journal of Manpower, 36(7), 9861011

Ministry of Higher Education, Malaysia (MOHE). (2006). Soft Skills Development Module for Malaysian Institutions of Higher Learning. Serdang: Universiti Putra Malaysia Press.

Moss, P., \& Tilly, C. (1996). "Soft" skills and race: an investigation of black men's employment problems. Work and Occupations, 23(3), 252-276.

Niazi, A. S. (2011). Training and development strategy and its role in organisational performance. Journal of Public Administration and Governance 1(2), 42-57.

Organisation for Economic Co-operation Development (OECD) (2016). OECD Economic Surveys: Malaysia 2016. Economic Assessment. Retrieved from https://dx.doi.org/10.1787/eco_surveys-mys-2016-en

Olexová, C. (2017). Establishing the financial returns arising from an evaluation of a retail training programme. Industrial and Commercial Training, 50(1), 20-31.

Otuko, A. H., Gabriel, K. C., \& Douglas, M. (2013). Effect of training dimensions on employee's work performance: a case of mumias sugar company in Kakamega County. International Journal of Business and Management Invention, 2(9), 138-149.

Penrose, E. T. (1959). The Theory of the Growth of the Firm. New York: John Wiley.

Rahman, A. A., Ng, S. I., Sambasivan, M., \& Wong, F. (2013). Training and organisational effectiveness: moderating role of knowledge management process. European Journal of Training and Development, 37(5), 472-488.

Rahman, W., \& Nas, Z. (2013). Employee development and turnover intention: theory validation. European Journal of Training and Development, 37(6), 564-579.

Rasul, M. S., Rauf, R. S. A., Mansor, A. N., Yasin, R. M., \& Mahamod, Z. (2013). Graduate employability for Manufacturing Industry. Procedia-Social and Behavioral Sciences 102, 242-25.

Roni, S. M., Djajadikerta, H., \& Ahmad, M. A. (2015). PLS-SEM Approach to second-order factor of deviant behavior: constructing perceived behavioural control. Procedia Economics and Finance, 28, 349-253.

Santos, A., \& Stuart, M. (2003). Employee perceptions and their influence on training effectiveness. Human Resource management Journal, 13(1), 27-45.

Sekaran, U. (2013). Research Method for Business: A Skill Building Approach (4 ${ }^{\text {th }}$ ed). John Wiley \& Sons.

Stam, M., \& Molleman, E. (1999). Matching the demand for the supply of IT professionals: towards a learning organization. International Journal of Manpower, 20(6), 375-387

Thang, N. N., Quang, T., \& Buyens, D. (2010). The relationship between training and firm performance: a literature review. Research and Practice in Human Resource Management, 18(1), 28-45.

Tharenou, P., Saks, A. M., \& Moore, C. (2007). A review and critique of research on training and organisational -level outcomes, Human Resource Management Review, 17(3), 251-273. 
Úbeda-García, M., Cortés, E.C., Marco-Lajara, B., \& Zaragoza-Sáez, P. (2014). Strategy, training and performance fit. International Journal of Hospitality Management, 42, 100116.

Wan Abdullah, W. A. (1994). Transnational corporations and human resource development: some evidence from the Malaysian manufacturing industries. Personnel Review, 23(5), $50-69$.

World Bank (2018). Malaysia Overview. Retrieved from http://www.worldbank.org/en/ country/malaysia/overview

World Bank (2020). World Development Indicators, Manufacturing, value added (\% GDP) Malaysia (Data $\quad$ file). $\quad$ Retrieved from https://data.worldbank.org/indicator/NV.IND.MANF.ZS?locations=MY

World Economic Forum (WEF). (2016). The Future of Jobs Employment, Skills and Workforce Strategy for the Fourth Industrial Revolution. Retrieved from http://www3.weforum.org/docs/WEF_Future_of_Jobs.pdf

Zainuddin, S. Z., Pillai, S., Dumanig, F. P., \& Phillip, A. (2019). English language and graduate employability. Education + Training, 61(1), 79-93. 